\title{
STRUKTUR SEMANTIS VERBA AKTIVITAS GIGI DALAM BAHASA JAWA: KAJIAN METABAHASA SEMANTIK ALAMI
}

\author{
SEMANTIC STRUCTURE OF JAVANESSE TEETH ACTIVITY VERB: \\ NATURAL SEMANTICS METALANGUAGE ANALYSIS
}

\author{
Ema Rahardian
}

\author{
Balai Bahasa Provinsi Jawa Tengah \\ Jalan Elang Raya 1, Mangunharjo, Tembalang, Semarang 50272, Jawa Tengah, Indonesia \\ ema.rahardian@gmail.com
}

(Naskah diterima tanggal 6 Februari 2021, direvisi terakhir tanggal 12 April 2021, dan disetujui tanggal 7 Mei 2021)

DOI: https:/ / doi.org/10.26499/wdprw.v49i1.783

\begin{abstract}
Javanese teeth activity is interested to be analyzed. It is because the Javanese language has various lexicons to express teeth activity. This paper aims to explore the semantic structure of Javanese teeth activity by using the theory of natural semantic metalanguage (NSM). The data used in this paper are taken from The Bausastra Jawa dictionary as well as data created by the researcher as a native Javanese speaker. The technique of data analysis in this study consists of four steps, namely determining the semantic primitive, deriving meaning, determining polysemy, dan paraphrasing the meaning. The result shows that Javanese teeth activity is realized into 23 lexicons, namely, mamah, ngilut, ngenyoh, nggayem, ngemah, nginang, nggondol, nyakot/nyokot, nggeget, ngeret, ngerot, nyathèk, ngerah, nyekit, nyisil, ngrokot, ngrikit, mbrakot, nglethak, nglethuk, nglethus, ngremus, and nglethik. Its semantic prime is melakukan/terjadi and its semantic component are mengunyah, membawa, menggigit, melepaskan, and mematahkan which is mapped based on the patient and instrumental relation.
\end{abstract}

Keywords: teeth activity; semantics structure; natural semantic metalanguage

\begin{abstract}
Abstrak
Verba aktivitas gigi dalam bahasa Jawa merupakan salah satu objek penelitian yang menarik untuk dikaji. Hal itu karena bahasa Jawa memiliki berbagai leksikon untuk mengungkapkan aktivitas gigi. Penelitian ini merupakan penelitian deskriptif kualitatif yang bertujuan untuk mendeskripsikan struktur semantis verba aktivitas gigi dalam bahasa Jawa dengan menggunakan teori metabahasa semantik alami. Data penelitian ini diperoleh dari kamus Bausastra Jawa dan data yang dikreasikan oleh peneliti sebagai penutur asli bahasa Jawa. Teknik analisis data dalam penelitian ini terdiri atas empat langkah, yaitu menentukan makna asali, menderivasi makna, menentukan polisemi, dan memarafrase makna. Hasil penelitian menunjukkan bahwa verba aktivitas gigi direalisasikan dalam 23 leksikon, yaitu mamah, ngilut, ngenyoh, nggayem, ngemah, nginang, nggondol, nyakot/nyokot, nggeget, ngeret, ngerot, nyathèk, ngerah, nyekit, nyisil, ngrokot, ngrikit, mbrakot, nglethak, nglethuk, nglethus, ngremus, dan nglethik. Leksikon-leksikon itu memiliki makna asali melakukan/terjadi dengan komponen semantis mengunyah, membawa, menggigit, melepaskan, dan mematahkan. Komponen semantis itu dipetakan berdasarkan hubungan pasien dan instrumen.
\end{abstract}

Kata-kata Kunci: aktivitas gigi; struktur semantik; metabahasa semantik alami 


\section{Pendahuluan}

Bahasa Jawa sebagai bahasa daerah yang dituturkan oleh masyarakat Jawa merupakan bahasa yang kaya kosakata. Kekayaan kosakata tersebut salah satunya dipicu oleh keanekaragaman leksikon untuk mengungkapkan aktivitas tertentu. Verba jatuh, misalnya, dalam bahasa Jawa memiliki berbagai leksikon untuk menggambarkan aktivitas jatuh dilihat dari posisi, penyebab, dan agen, seperti kata jungkel, jungkir, dan jongor. Ketiga kata itu masing-masing mewakili konsep jatuh yang berbeda-beda. Kata jungkel merupakan verba jatuh yang mengandung konsep jatuh ke depan dengan posisi kepala terperosok; kata jungkir mengandung konsep jatuh ke depan dengan posisi terbalik; kata jongor mengandung konsep jatuh ke depan dengan posisi muka terkena dasar. Ketiga verba jatuh dalam bahasa Jawa tersebut mewakili agen yang berbeda-beda. Kata jungkel dan jongor untuk manusia, sementara kata jungkir digunakan untuk benda.

Tidak hanya kelas kata verba. Kelas kata lain, seperti nomina pun demikian. Kata padi, misalnya, memiliki berbagai macam leksikon yang memiliki relasi makna, seperti gabah, kapak, menir, dan las. Keempat kata yang berkaitan dengan padi tersebut pun mewakili konsep makna yang berbeda-beda. Kata gabah mewakili konsep butiran padi yang baru saja dilepaskan dari batangnya, kapak merupakan gabah yang kopong tinggal kulitnya saja, menir adalah beras yang butirannya tidak utuh dan halus, las ialah butiran gabah yang tercampur di dalam beras.

Kekayaan kata dan makna yang ada dalam bahasa Jawa inilah yang mendasari peneliti mengkaji makna verba aktivitas gigi dalam bahasa Jawa. Melalui analisis ini diperoleh gambaran struktur semantis leksikon-leksikon yang berkaitan dengan aktivitas gigi.
Givon (1984: 51--52) mengungkapkan bahwa verba dimotivasi oleh peristiwa. Sebagai suatu peristiwa, verba digolongkan ke dalam verba keadaan, proses, dan tindakan. Perbedaan ketiganya ada pada kestabilan waktu, yaitu stabil (verba keadaan), kurang stabil (verba proses), dan tidak stabil (verba tindakan). Dalam hal ini semakin stabil waktu menandakan verba tersebut tidak mengalami perubahan waktu.

Untuk lebih jelas, berikut ini penjelasan masing-masing tipe verba melalui tabel komponen semantik verba. (Subiyanto, 2011: 167).

Tabel 1

Komponen Semantik Verba

\begin{tabular}{lccc}
\hline Komponen & \multicolumn{3}{c}{ Tipe Verba } \\
\cline { 2 - 4 } Semantis & Verba & Verba & Verba \\
& Keadaan & Proses & Tindakan \\
\hline Dinamis & - & + & + \\
Kesengajaan & - & - & + \\
Kepungtualan & - & $-/+$ & $-/+$ \\
Aspek/Telik & - & $-/+$ & $-/+$ \\
Kinesis & - & - & $-/+$ \\
\hline
\end{tabular}

Dari kelima komponen semantis itu, hal yang membedakan verba tindakan dengan verba lainnya adalah komponen kesengajaan. Komponen kesengajaan terjadi karena ada unsur kesengajaan yang dilakukan oleh pelaku. Dengan kata lain, pelaku menghendaki peristiwa itu terjadi. Verba menyiram, misalnya, memiliki ciri kesengajaan, sementara verba senang tidak memiliki ciri ini. Untuk itu, verba menyiram dikategorikan sebagai verba tindakan.

Begitu juga dengan verba aktivitas gigi. Verba aktivitas gigi termasuk ke dalam verba tindakan karena memiliki komponen makna [+dinamis], [+sengaja], dan [+kinesis].

Dalam bahasa Jawa, verba aktivitivas gigi direalisasikan dengan beberapa leksikon yang secara makna berdekatan. Leksikon mamah dan ngenyoh, misalnya, sama-sama memiliki 
komponen makna [+dinamis], [+sengaja], [+kinesis], [-aspek], dan [-pungtual]. Berdasarkan komponen maknanya, kedua kata itu tidak memiliki perbedaan. Namun, apabila dikaji lebih dalam, kedua kata itu memiliki perbedaan dalam hal kuat tidaknya gigitan yang disebabkan oleh kekerasan objek yang digigit. Kata ngenyoh digunakan untuk merujuk aktivitas gigi ketika menggigit dan mengunyah sesuatu yang keras sehingga memerlukan tenaga lebih.

Berkaitan dengan hal itu, kedekatan makna antarleksikon tidak dapat hanya dijelaskan melalui analisis komponen makna. Dalam hal ini perlu analisis mendalam menggunakan pisau analisis metabahasa semantik alami agar makna setiap leksikon dapat dijelaskan dengan baik.

Metabahasa semantik alami atau natural semantics metalanguage merupakan teori yang dipelopori oleh Anna Wierzbicka, seorang linguis keturunan Polandia. Goddard (1996: 2) mengatakan bahwa metabahasa semantik alami (MSA) merupakan analisis makna yang mampu menjelaskan makna sebuah kata dengan jelas, tidak berputar-putar, dan tanpa residu. Pada teori MSA terdapat konsep teoretis yang mendukung analisis data, yaitu makna asali, polisemi, dan sintaksis sebagai perangkat analisisnya.

Makna asali dalam MSA merupakan konsep awal dalam penganalisisan. Aristoteles mengungkapkan bahwa dengan adanya makna asali ini, definisi makna sebuah kata dapat lebih dipahami (Wierzbicka, 1996: 10).

Goddard (2012: 714) mencatat ada 66 makna asali yang beberapa di antaranya sebagai berikut.

1. Substantive: I 'aku', you ' $\mathrm{kau} / \mathrm{kamu}^{\prime}$, someone 'seseorang' something/thing 'sesuatu', people 'orang', body 'badan'.

2. Relational: kind 'jenis', part 'bagian'.

3. Determiners: this 'ini', the same 'sama', other/else 'lain'.
4. Quantifiers: one 'satu', two 'dua', all 'semua', many/much 'banyak', some 'beberapa'.

5. Evaluators: good 'baik', bad 'buruk'.

6. Descriptors: big 'besar', small 'kecil'.

7. Mental Predicates: think 'pikir', know 'tahu', want 'mau/ingin', feel 'rasa', see 'melihat', hear'dengar'.

8. Speech: say 'ujar', words 'kata-kata', true 'benar'.

9. Action, Events, Movements, Contact: do 'berbuat', happen 'terjadi', move 'bergerak', touch 'menyentuh'

10. Location, Existence Possessions, and Specification: be (somehere) 'sesuatu tempat', there, is/exist 'ada', have 'memiliki' be (someone/something) 'menjadi sesuatu/seseorang'

11. Life and Death: live 'hidup', die 'mati'

12. Time: when/time 'bila atau kapan/waktu', now 'sekarang', before 'sebelum', after 'sesudah', a long time 'lama', a short time 'sekejap', for sometime 'beberapa saat', moment 'waktu/saat'.

13. Space: where/place 'di mana/ tempat', here 'di sini', above 'di atas', below 'di/ke bawah', far 'jauh', near 'dekat', side 'sebelah, inside 'di dalam'.

14. Logical Concept: not 'tidak', may be 'mungkin', can 'dapat', because 'sebab', if 'jika' / kalau'.

15. Intensifiers/Augmentor: very 'sangat', more 'lagi'.

16. Similarity: like/as 'seperti'.

Berkaitan dengan daftar makna asali tersebut, verba aktivitas gigi memiliki komponen action, events, movements, contact 'tindakan, peristiwa, gerakan, dan kontak'.

Konsep dasar lain dalam teori MSA adalah polisemi. Polisemi merupakan leksikon tunggal yang mengekspresikan dua makna asali yang berbeda. Di antara dua makna asali itu terdapat hubungan nonkomposisi karena tiap-tiap leksikon 
memiliki kerangka gramatika yang berbeda. Goddard (1996: 31) mengungkapkan ada dua hubungan nonkomposisi yang paling kuat, yakni entailment-like relationship 'hubungan pengartian' dan implicational relationship 'hubungan implikasi'. Pertama, hubungan pengartian tampak dalam eksponen melakukan/terjadi dan melakukan pada/terjadi, yakni jika X melakukan sesuatu pada Y, sesuatu terjadi pada Y. Kedua, hubungan implikasi dalam eksponen terjadi dan merasakan, yaitu jika X merasakan sesuatu, sesuatu terjadi pada X.

Konsep terakhir adalah sintaksis makna universal (SMU). Goddard (1996: 24) mengungkapkan bahwa SMU adalah kombinasi dari butir-butir leksikon makna asali yang membentuk proposisi sederhana sesuai dengan perangkat morfosintaksisnya.

Ketiga konsep dasar tersebut digunakan untuk menganalisis makna verba aktivitas gigi dalam bahasa Jawa dengan pendekatan MSA. Dengan demikian, perbedaan makna dapat lebih jelas dideskripsikan.

Penelitian semantik dengan pisau analisis metabahasa semantik alami pernah dilakukan oleh peneliti-peneliti Indonesia dengan objek kajian kosakata, baik bahasa Indonesia, asing, maupun bahasa-bahasa di nusantara.

Penelitian dengan objek kajian kosakata bahasa asing pernah dilakukan oleh Dewi (2019). Dalam penelitiannya, Dewi (2019: 101) mengaplikasikan teori MSA untuk mendeskripsikan makna verba kiru 'potong' dalam bahasa Jepang. Verba kiru 'potong' terbentuk dari makna asali melakukan dan terjadi dengan sintaksis $\mathrm{X}$ melakukan sesuatu pada $\mathrm{Y}$, sesuatu terjadi pada $\mathrm{Y}$.

Sementara itu, penelitian dengan objek kajian kosakata bahasa Indonesia pernah dilakukan oleh Syahputra dan Sinar (2018). Syahputra dan Siniar mengkaji verba sentuh dalam bahasa Indonesia melalui artikel berjudul "Struktur Semantis Verba Sentuh Bahasa Indonesia". Syahputra dan Sinar mendeskripsikan kategorisasi makna, jenis makna, dan struktur semantis yang dimiliki oleh verba sentuh dalam bahasa Indonesia. Mereka menemukan ada empat makna asali dalam pembentukan verba sentuh, yaitu merasakan, memukul, menekan, dan menggosok. Di samping itu, mereka juga menemukan komponen sesuatu dan seseorang dalam verba sentuh bahasa Indonesia (Syahputra dan Sinar, 2018: 88--89).

Penelitian semantik dengan objek kajian kosakata bahasa di Nusa Tenggara Timur juga pernah dilakukan oleh Tualaka (2016) dan Loe (2017). Tualaka mengkaji struktur semantik verba persepsi dalam bahasa Melayu Kupang, NTT. Melalui penelitiannya tersebut Tualaka (2016: 57) menemukan bahwa verba persepsi bahasa Melayu Kupang dibentuk dari predikat mental melihat dengan sub-tipe merasakan, mengetahui, dan mengatakan.

Adapun Loe mengkaji verba melukai dalam bahasa Rote dialek Dengka, NTT. Loe (2017: 221) menyebutkan bahwa leksikon $u t a$, tati, mbau, donggi, dui, undu, teta, ela, kalu, ali, isi, i? i, tede, soso, nato, edo, ule, tutu, dan dodo dalam bahasa Rote memiliki medan makna yang sama. Perbedaan makna di antara leksikon-leksikon itu antara lain berkaitan dengan posisi bagian tubuh yang digunakan untuk melukai.

Kajian metabahasa semantik alami juga pernah dilakukan oleh Kurniawan dan Rahayu yang sama-sama mengkaji kosakata bahasa Sasak. Dalam artikel berjudul "Leksikon Emotif Makna 'Ketidaksukaan' dalam Bahasa Sasak: Kajian Metabahasa Semantik Alami", Kurniawan (2014: 50) mendeskripsikan bahwa leksikon emotif dalam bahasa Sasak yang bermakna 'ketidaksukaan' dibedakan atas dua hal, yaitu disebabkan oleh subjek lain dan diri sendiri.

Berbeda dengan Kurniawan, Rahayu dkk. (2020: 41) mengkaji kosakata bahasa Sasak yang memiliki medan makna 'memukul'. Rahayu menemukan bahwa 
verba memukul dalam bahasa Sasak terealisasi ke dalam 26 leksikon. Perbedaan di antara leksikon-leksikon itu ada pada tujuan, cara, dan alat memukul.

Kajian metabahasa semantik alami dengan objek kajian bahasa di daerah Sumatera pernah dilakukan oleh Mulyadi (2013). Pada artikel yang dimuat dalam prosiding Language Maintenance and Shift III, Mulyadi mengkaji kategorisasi dan makna verba mirip takut dalam bahasa Melayu Asahan. Melalui kajian itu, ditemukan bahwa bahasa Melayu Asahan dibentuk oleh komponen evaluatif dengan subkategori aku tidak menginginkan ini, aku tidak dapat melakukan apa pun, dan aku tidak dapat berpikir sekarang. Adapun makna verba tersebut dicirikan oleh elemen peristiwa, pengetahuan, tindakan, dan temporal (Mulyadi, 2013: 335).

Ndruru (2020: 922) dalam artikel berjudul “Makna Verba 'Membersihkan' dalam Bahasa Nias: Pendekatan Metabahasa Semantik Alami" menyebutkan bahwa melalui penerapan MSA, perbedaan makna verba membersihkan dalam bahasa Nias dapat lebih terlihat. Perbedaan makna itu berkaitan dengan entitas, cara, alat, dan hasil.

Maturbongs (2016) melalui artikel berjudul "Peran Semantis Verba Bahasa Abun" mencoba mengeksplorasi kekayaan verba-verba bahasa Abun di Papua menggunakan teori MSA. Melalui penelitian itu, Maturbongs (2016: 35) menemukan bahwa verba keadaan bahasa Abun cenderung menonjolkan keadaan fisik dan pikiran. Peran semantis verba tindakan dalam bahasa Abun merepresetasikan makna alamiah perbuatan, terjadi, dan perpindahan/pergerakan. Adapun verba proses dalam bahasa Abun memiliki keteraturan dalam hal pergerakan dan aktivitas.

Yulianti dan Suktiningsih pernah meneliti kosakata bahasa Sunda menggunakan teori MSA. Yulianti (2016: 74) mengkaji kosakata warna dalam bahasa Sunda dan menemukan bahwa konsep warna dalam bahasa Sunda memiliki ciri kedaerahan yang kuat dan tidak memiliki padanan dalam bahasa Indonesia, seperti ngagedod dan lestreng.

Suktiningsih (2017) mengkaji struktur semantis verba mawa 'membawa'. Suktiningsih (2017: 1) mendeskripsikan bahwa verba mawa 'membawa' yang direalisasikan ke dalam leksikon nyuhun, mangoul, gotong, mikul, gandong, ngais, nyoren, nangkod, munggu, gembol, jingjing, ngelek, nyalempang, dan nyeret memiliki komposisi polisemi tindakan, yaitu melakukan dan pindah.

Widani (2017) mengkaji konfigurasi makna verba tindakan mengambil dalam bahasa Bali menggunakan teori metabahasa semantik alami. Berdasarkan analisis ditemukan bahwa verba mengambil dalam bahasa Bali diekspresikan dalam beberapa leksikon, yaitu nyemak/ngambil, nyuang, nyurud, nuduk, ngalap, nimba, ngotèk, nyèndok, ngarebut, nyopèt, ngarampok, nyambrèt, ngamaling, dan ngutil/ngalamit (Widani, 2017: 127).

Parwati (2018: 121) dalam artikel berjudul "Verba Memasak dalam bahasa Bali: Kajian Metabahasa Semantik Alami (MSA)" menemukan bahwa hubungan nonkomposisi verba memasak adalah melakukan dan terjadi dengan pola sintaksis $X$ melakukan sesuatu pada Y dan Y masak/matang (termasak).

Sementara itu, kekhasan kosakata bahasa Osing juga pernah dikaji oleh Khrisnantara dkk. (2020) dalam artikel yang berjudul “Struktur Semantik Verba 'Membawa' dalam Bahasa Osing Banyuwangi". Verba membawa dalam bahasa Osing dibentuk dari makna asali melakukan dan berpindah yang terealisasi dalam beberapa butir leksikon, di antaranya nyangking, mikul, nyuwun, ngendong, dan ngemplok (Khrisnantara dkk., 2020: 96).

Adapun penelitian semantik dalam bahasa Jawa, pernah dilakukan oleh Subiyanto, Mayasari, dan Nardiati. Subiyanto 
(2011) dalam artikelnya meneliti struktur semantis verba proses tipe kejadian dalam bahasa Jawa. Melalui penelitian tersebut, Subiyanto (2011: 165) menemukan bahwa komponen semantis verba kejadian, antara lain, [+dinamis], [-kesengajaan], [+/kepungtualan], [+/-telik], [-kinesis], dan [gerakan]. Selain itu, Subiyanto juga menemukan bahwa verba kejadian dibentuk dari makna asali terjadi dan melakukan.

Kajian struktur semantis verba emosi dalam bahasa Jawa juga pernah dilakukan oleh Mayasari (2020) yang mengkaji verba emosi sedih. Mayasari (2020: 375) mendeskripsikan bahwa emosi sedih merupakan verba proses tipe keadaan yang memiliki turunan makna dengan tingkatan sedih dari tinggi hingga rendah. Urutan leksikon tersebut adalah nelongso, rumangsa apes, ngenes, loro, sungkwa, rimang, nglangut, dan kingkin.

Sementara itu, penelitian semantik dengan pisau analisis semantik struktural pernah dilakukan oleh Nardiati (2017) yang meneliti komponen makna leksem emponempon dalam bahasa Jawa. Melalui penelitian itu, Nardiati (2017: 165) menemukan ada empat belas leksem yang berkonsep emponempon berdasarkan dimensi anatomi, tumbuhan, batang, bunga, akar, khasiat, warna, dan tekstur. Dalam penelitian ini, Nardiati menggunakan analisis semantik struktural.

Sementara itu, verba aktivitas gigi dalam bahasa Jawa dengan pendekatan metabahasa semantik alami belum pernah dikaji oleh para peneliti. Untuk itu, kajian ini perlu dilakukan guna memberi gambaran perbedaan makna yang jelas pada verba aktivitas gigi dalam bahasa Jawa. Hasil penelitian ini juga diharapkan dapat memberikan kontribusi positif terhadap leksikograf dalam pemaknaan kamus ekabahasa bahasa Jawa.

\section{Metode}

Penelitian ini merupakan penelitian deskriptif kualitatif sehingga analisis yang dihasilkan berupa penjelasan tentang makna kata secara tuntas. Miles dkk. (2014: 4) menyebutkan bahwa data kualitatif merupakan sumber deskripsi yang kaya dan menggambarkan objek secara menyeluruh. Untuk itu, dalam penelitian kualitatif ini sangat penting menentukan data yang asli tanpa rekaan agar dapat menyajikan hasil yang maksimal dan apa adanya.

Penulis mengumpulkan data dari berbagai sumber, antara lain kamus Bausastra Jawa serta data yang dikreasikan oleh peneliti sebagai penutur asli bahasa Jawa. Pengumpulan data dilakukan dengan menggunakan teknik catat.

Teknik analisis data yang digunakan adalah tahapan analisis metababahasa semantik alami dengan langkah-langkah sebagai berikut. Pertama, mengumpulkan data kemudian mencatat dan menentukan makna asalinya. Kedua, mencari derivasi makna sehingga properti semantis setiap data bisa terdeteksi untuk mengetahui perbedaannya. Ketiga, mencari polisemi sebagai dasar pembentukan sintaksis makna universal dengan cara membandingkan properti semantis setiap data. Keempat, memarafrase makna setiap data.

Hal yang membedakan antara analisis metabahasa semantik alami dan analisis semantik lain adalah analisis metabahasa semantik alami menyelidiki makna yang menggunakan makna asali dan menghindari penggunaan fitur serta pemarkah artifisial, seperti penggunaan simbol (-) dan (+). Untuk itu, dalam deskripsi analisis penelitian ini tidak ditemukan pemarkah artifisial untuk mengidentitasi makna leksikon. 


\section{Hasil dan Pembahasan}

Verba aktivitas gigi dalam bahasa Jawa direalisasi dalam 23 leksikon, yaitu mamah, ngilut, ngenyoh, nggayem, ngemah, nginang, nggondol, nyakot/nyokot, nggeget, ngeret, ngerot, nyathèk, ngerah, nyekit, nyisil, ngrokot, ngrikit, mbrakot, nglethak, nglethuk, nglethus, ngremus, dan nglethik. Leksikon-leksikon itu mewakili makna yang berbeda-beda bergantung pada pasien dan instrumennya. Dalam hal ini pasien berkaitan dengan objek yang dikenai perbuatan. Sementara itu, instrumen berkaitan dengan cara melakukan tindakan.

Verba aktivitas gigi dalam bahasa Jawa memiliki struktur semantis yang terbentuk dari makna asali melakukan/terjadi dengan komponen seseorang/sesuatu $X$ melakukan sesuatu kepada seseorang/sesuatu $Y$ dengan sebuah cara sehingga sesuatu terjadi pada seseorang/sesuatu Y. Makna asali melakukan/terjadi tersebut menurunkan beberapa makna, yaitu mengunyah, membawa, menggigit, melepaskan, dan mematahkan.

Turunan makna itu muncul berdasarkan pemaknaan bahwa seseorang/sesuatu melakukan sesuatu, ia ingin mengunyah-nya. Ketika ia melakukan sesuatu menggunakan gigi, ia seperti menggigit, mematahkan, dan melepaskan-nya. Apabila seseorang/sesuatu melakukan sesuatu dengan tujuan tertentu, ia akan membawa menggunakan giginya.

Berikut ini deskripsi tiap-tiap leksikon yang dikategorikan berdasarkan makna turunannya.

\subsection{Verba Aktivitas Gigi Mengunyah}

Makna mengunyah mewadahi makna leksikon mamah, ngilut, ngenyoh, nggayem, ngemah, dan nginang. Makna mengunyah terbentuk atas dasar struktur semantis:

$X$ melakukan sesuatu kepada $Y$

$\mathrm{X}$ menghaluskan $\mathrm{Y}$ menggunakan gigi (dalam waktu tertentu)

Sesuatu terjadi pada $Y$
$Y$ menjadi semacam ini

X melakukan sesuatu kepada $Y$

Leksikon mamah, ngilut, ngenyoh, nggayem, ngemah, dan nginang memiliki perbedaan semantis pada durasi dan proses setelah sesuatu itu halus. Urutan leksikon yang memiliki durasi mengunyah paling singkat adalah ngemah, mamah, ngenyoh, ngilut, nginang, kemudian nggayem.

Perbedaan lainnya adalah proses yang terjadi setelah sesuatu yang dikunyah halus. Leksikon mamah, ngilut, dan ngenyoh adalah verba yang mengandung konsep menelan makanan yang telah halus. Sedangkan, leksikon nggayem merupakan verba yang mengandung konsep mengeluarkan kembali makanan ke mulut setelah ditelan untuk diproses lagi dengan gigi. Adapun ngemah adalah verba yang mengandung konsep mengeluarkan makanan yang telah halus untuk diberikan kepada orang lain atau dibuang. Sementara nginang adalah verba yang mengandung konsep mengunyah kinang untuk dikulum.

Berikut ini contoh leksikon tersebut dalam kalimat.

(a) Simbah mamah sega.

'Nenek mengunyah nasi'.

(b) Pakdhé ngilut kuluban bèn alus.

'Paman mengunyah (agak lama) sayuran agar halus'.

(c) Panganané Siti sajaké atos nganti dhèknèn tenanan yèn ngenyoh.

'Makanan Siti sepertinya keras sampai dia mengunyah dengan kuat'.

(d) Sapi nggayemi suket nang sawah. 'Sapi mengunyah (kemudian dikeluarkan lagi) rumput di sawah'.

(e) Ibu ngemah sega dinggo adik.

'Ibu mengunyah (sampai setengah halus) nasi untuk adik'.

(f) Saben isuk Mbah Putri nginang ning jogan. 
'Setiap pagi Mbah Putri menginang di teras'.

Perbedaan leksikon mamah, ngilut, ngenyoh, nggayem, ngemah, dan nginang masing-masing digambarkan melalui parafrase berikut.

mamah 'mengunyah'

X melakukan sesuatu kepada $Y$

$\mathrm{X}$ menghaluskan $\mathrm{Y}$ menggunakan gigi

Sesuatu terjadi pada $Y$

$\mathrm{Y}$ telah halus

X menelan Y (karena telah halus)

ngilut 'mengunyah' (dalam waktu lama)

$X$ melakukan sesuatu kepada $Y$

$\mathrm{X}$ menghaluskan $\mathrm{Y}$ menggunakan gigi (dalam waktu yang lama)

Sesuatu terjadi pada $Y$

$\mathrm{Y}$ telah halus

$X$ menelan $Y$ (karena telah halus)

ngenyoh 'mengunyah sesuatu yang keras'

$X$ melakukan sesuatu kepada $Y$

$X$ menghaluskan $Y$ menggunakan gigi

Y memiliki tekstur agak keras

$\mathrm{X}$ tampak seperti mengeluarkan tenaga

yang lebih

Sesuatu terjadi pada $Y$

Y telah halus

$X$ menelan $Y$

nggayem 'mengunyah' (kemudian

dikeluarkan lagi untuk dihaluskan kembali)

$X$ melakukan sesuatu kepada $Y$

$X$ adalah binatang pemamah biak

$X$ menghaluskan Y menggunakan gigi

Sesuatu terjadi pada $Y$

$Y$ telah setengah halus

$X$ menelan $Y$
$X$ mengeluarkan $Y$ di mulut

$X$ mengunyah $Y$ kembali

Sesuatu terjadi pada $Y$

Y telah halus

$X$ menelan $Y$

ngemah 'mengunyah' (setengah halus untuk diberikan kepada orang lain)

X melakukan sesuatu kepada $Y$

$X$ menghaluskan $Y$ dengan gigi

Sesuatu terjadi pada $Y$

$Y$ telah setengah halus

$X$ mengeluarkan $Y$ dari mulut

$X$ memberikan $Y$ kepada $Z$

nginang 'menginang'

X melakukan sesuatu kepada $\mathrm{Y}$

Y adalah kinang

$\mathrm{X}$ menghaluskan $\mathrm{Y}$

Sesuatu terjadi pada $Y$

Y telah halus

$X$ mengulum $Y$ di mulut

\subsection{Verba Aktivitas Gigi Membawa}

Verba aktivitas gigi yang memiliki makna membawa adalah nggondol. Leksikon nggondol merupakan verba yang memiliki konsep aktivitas yang biasa dilakukan hewan ketika membawa mangsa dengan gigi.

Realisasi verba ini di dalam kalimat adalah sebagai berikut.

(g) Kucinge Siti nggondol gerèhé Sulé. 'Kucing milik Siti membawa (dengan gigi) ikan asin milik Sule'.

Eksplikasi leksikon nggondol ini dapat digambarkan dengan parafrase berikut.

nggondol 'membawa' (menggunakan gigi)

X melakukan sesuatu kepada $Y$ 
$X$ adalah hewan pemangsa

$\mathrm{X}$ membawa $\mathrm{Y}$ menggunakan gigi ke suatu tempat

Sesuatu terjadi pada $Y$

\subsection{Verba Aktivitas Gigi Menggigit}

Verba aktivitas gigi yang memiliki makna menggigit, yaitu nyakot/nyokot, nggeget, ngeret, nyathèk, ngerah, dan nyekit. Pengelompokan leksikon ini berdasarkan struktur semantis berikut.

X melakukan sesuatu kepada Y karena disebabkan oleh sesuatu

$\mathrm{X}$ menekan $\mathrm{Y}$ menggunakan gigi tertentu $X$ menekan $\mathrm{Y}$ dalam waktu tertentu

Terjadi sesuatu seperti ini pada $Y$

Melalui struktur semantis itu, tampak bahwa leksikon dengan makna menggigit memiliki perbedaan dalam durasi, cara, dan penyebab.

Durasi berkaitan dengan lama-tidaknya gigitan. Urutan leksikon yang mengandung durasi paling lama dalam menekan adalah ngeret, nggeget, ngerah, nyathèk, nyekit, dan nyakot/nyokot.

Cara berkaitan dengan bagian gigi yang digunakan untuk menggigit sehingga menghasilkan tekanan tertentu. Urutan leksikon yang mengandung tekanan paling kuat hingga kurang kuat adalah nggeget, nyakot/nyokot, ngerah, nyathèk, nyekit, dan ngeret.

Perbedaan leksikon-leksikon tersebut tampak pada contoh berikut.

(h) Siti nyakot/nyokot tangané Sulé merga Sulé nakal.

'Siti menggigit tangan Sule karena Sule nakal'.

(i) Wong kang lara tetanus biasané dikongkon nggeget séndok.

'Orang yang sakit tetanus biasanya disuruh menggigit (dalam waktu lama) sendok.' (j) Mbak Yanti yèn turu mesthi ngeret.

'Mbak Yanti kalo tidur selalu mengerut.'

(k) Adik yen ngerot mesthi banter.

'Adik ketika mengerut selalu terdengar keras'.

(1) Asuné Koko senengané nyathèk.

'Anjing Koko suka menggigit.'

(m) Kucingé Siti kudu dicekeli. Yèn ora, mesthi ngerah kucing liya.

'Kucing Siti harus dipegangi. Jika tidak, akan menggigit kucing lain.'

(n) Semut abang yèn nyekit lara.

'Semut merah jika menggigit sakit.'

Perbedaan makna leksikon-leksikon itu dapat dengan jelas dilihat pada parafrase berikut.

\section{nyakot 'menggigit'}

X melakukan sesuatu kepada $Y$ karena $X$ ingin menahan $Y$ mengggunakan gigi

$X$ menekan $Y$ menggunakan gigi seri

$X$ menekan $Y$ dalam waktu singkat

Sesuatu terjadi pada $Y$

Y bisa jadi berbekas atau terluka dan masih utuh

Leksikon nyakot kadang kala diucapkan dengan nyokot. Perbedaan pengucapan ini bergantung pada wilayah tuturnya.

nggeget 'menggigit' (dengan kuat dan lama),

X melakukan sesuatu kepada $\mathrm{Y}$ karena ingin menahan $Y$ menggunakan gigi

$X$ menekan $Y$ menggunakan gigi seri

$X$ menekan $Y$ dalam waktu lama dan kuat

Sesuatu terjadi pada $Y$

Y bisa jadi berbekas atau terluka dan masih utuh

ngeret 'mengerut' 
X melakukan sesuatu kepada Y karena kebiasaan

$\mathrm{Y}$ adalah gigi $\mathrm{X}$

$\mathrm{X}$ menekan $\mathrm{Y}$ dengan menggesek berulang-ulang sehingga terdengar bunyi kret-kret

$X$ melakukannya dalam keadaan tidur

Sesuatu terjadi pada $Y$

$\mathrm{Y}$ masih utuh

ngerot 'mengerut'

X melakukan sesuatu kepada $\mathrm{Y}$ karena kebiasaan

$\mathrm{Y}$ adalah gigi $\mathrm{X}$

$X$ menekan $Y$ dengan menggesek berulang-ulang sehingga terdengar bunyi krot-krot

$\mathrm{X}$ melakukannya dalam keadaan tidur

Sesuatu terjadi pada $Y$

$\mathrm{Y}$ masih utuh

nyathek 'menggigit' (dilakukan oleh hewan bergigi)

X melakukan sesuatu kepada Y karena terprovokasi

$X$ adalah hewan bergigi

$X$ menekan $Y$ menggunakan gigi

Sesuatu terjadi pada $Y$

Y bisa jadi berbekas atau terluka dan masih utuh

ngerah 'menggigit' (biasanya dilakukan hewan ketika bertengkar)

X melakukan sesuatu kepada Y ketika bertengkar

$X$ adalah hewan bergigi

$X$ menekan $Y$ menggunakan gigi

Sesuatu terjadi pada $Y$

Y bisa jadi berbekas atau terluka dan masih utuh nyekit 'menggigit' (biasanya dilakukan hewan kecil bergigi)

X melakukan sesuatu kepada Y karena terprovokasi

$X$ adalah hewan kecil bergigi

$X$ menekan $Y$ menggunakan gigi

Sesuatu terjadi pada $Y$

Y bisa jadi berbekas atau terluka dan masih utuh

\subsection{Verba Aktivitas Gigi Melepaskan}

Leksikon-leksikon aktivitas gigi dalam bahasa Jawa yang memiliki makna melepaskan adalah nyisil, ngrokot, ngrikit, dan mbrakot. Makna melepaskan ini berkaitan dengan memisahkan bagian benda yang satu dengan yang lain menggunakan gigi.

Berikut contoh kalimat leksikon-leksikon tersebut.

(o) Siti nyisil kuaci.

'Siti menyisil kuaci'.

(p) Sulé ngrokoti pelem.

'Sule makan (dengan cara menggigit daging buah) mangga'.

(q) Awit wingi bengi aku krungu suara tikus ngrikiti kabel.

'Sejak tadi malam saya mendengar suara tikus makan (dengan cara menggigit benda sedikit-demi sedikit sampai menimbulkan suara) kabel'.

(r) Sulé mbrakoti balungan sapi.

'Sule makan (dengan cara menggigit daging hewan yang menempel di tulang) tulang sapi'.

Pengelompokan leksikon-leksikon tersebut berdasarkan pada struktur semantis berikut.

X melakukan sesuatu kepada $Y$

$\mathrm{Y}$ adalah sesuatu

$X$ melepaskan $Y$ dengan cara tertentu 
Terjadi sesuatu pada Y dengan kondisi tertentu.

Berdasarkan struktur semantis tersebut, verba aktivitas gigi melepaskan berkaitan dengan apa yang digigit, cara menggigit, dan bagaimana hasil gigitan. Berikut ini eksplikasi tiap-tiap leksikon tersebut.

nyisil 'membuka kulit' (menggunakan gigi seri),

$X$ melakukan sesuatu kepada $Y$

$Y$ adalah biji-bijian yang berkulit

$\mathrm{X}$ melepaskan kulit Y menggunakan gigi seri

$\mathrm{X}$ melakukannya dengan bantuan lidah

Sesuatu terjadi kepada $Y$

kulit $\mathrm{Y}$ terlepas

ngrokot 'menggigit daging buah'

$X$ melakukan sesuatu kepada $Y$

$\mathrm{Y}$ adalah buah-buahan

$\mathrm{X}$ melepaskan daging $\mathrm{Y}$ dari tempatnya menempel (kulit atau biji)

$X$ melakukan dengan mulut terbuka lebar

Sesuatu terjadi pada $Y$

$\mathrm{Y}$ terlepas dengan gigitan yang besar

ngrikit 'menggigit benda dengan gigitan kecil'

$X$ melakukan sesuatu kepada $Y$

$\mathrm{Y}$ adalah benda atau buah

$\mathrm{X}$ melepaskan $\mathrm{Y}$ dari tempatnya menempel

X melakukannya sedikit demi sedikit sehingga terdengar bunyi krit

Sesuatu terjadi pada $Y$

$\mathrm{Y}$ terlepas dengan gigitan kecil-kecil

mbrakot 'menggigit daging hewan'

$X$ melakukan sesuatu kepada $Y$
$\mathrm{Y}$ adalah hewan

$\mathrm{X}$ melepaskan daging $\mathrm{Y}$ dari tempatnya menempel (tulang)

$X$ melakukan dengan mulut terbuka lebar

Sesuatu terjadi pada $Y$

$\mathrm{Y}$ terlepas dengan gigitan yang besar

\subsection{Verba Aktivitas Gigi Mematahkan}

Leksikon verba aktivitas gigi yang memiliki makna mematahkan ini adalah nglethak, nglethuk, nglethus, ngremus, dan nglethik. Makna mematahkan berkaitan dengan aktivitas gigi yang membuat sebuah benda terbagi menjadi beberapa bagian.

Berikut ini contoh leksikon tersebut dalam kalimat.

(s) Tono nglethak ès batu sing jik utuh. 'Tono menggigit (dengan cara mematahkan benda yang keras) es batu yang masih utuh'.

(t) Mbak Yem nglethuk lanthing. 'Mbak Yem menggigit kue lanting'.

(u) Ijah nglethus lombok. 'Ijah menggigit cabai'.

(v) Dono ngremus pil lara weteng. 'Dono menggigit pil sakit perut.

(w) Parjo nglethik janjanan stik kéju. 'Parjo menggigit kue stik keju'.

Leksikon-leksikon itu memiliki perbedaan yang mendasar pada wujud benda yang digigit dan cara mematahkan benda menggunakan gigi tertentu.

Leksikon nglethak, nglethuk, dan ngremus mengacu aktivitas gigi geraham untuk menggigit benda yang keras dengan ukuran benda yang besar (nglethak), agak besar (nglethuk), dan kecil (ngremus). Sementara itu, leksikon nglethus mengacu pada aktivitas gigi seri untuk menggigit benda yang agak besar tapi kopong dan leksikon nglethik mengacu pada aktivitas 
gigi untuk menggigit benda keras yang tipis.

Di samping itu, perbedaan mendasar kelima leksikon tersebut terletak pada posisi mulut sehingga tercipta suara yang berbedabeda ketika benda terpatahkan.

Secara umum, pemetaan struktur semantis verba jenis ini adalah sebagai berikut.

\section{X melakukan sesuatu kepada $Y$}

$\mathrm{Y}$ adalah benda dengan ukuran dan kekerasan tertentu

$\mathrm{X}$ mematahkan $\mathrm{Y}$ dengan gigi tertentu sehingga terdengar bunyi

Sesuatu terjadi pada $Y$

$Y$ menjadi semacam ini

Untuk lebih jelasnya, berikut ini parafrase masing-masing leksikon-leksikon tersebut.

nglethak'menggigit benda keras'

X melakukan sesuatu kepada $Y$

$X$ melakukan menggunakan geraham

$Y$ adalah benda keras

$\mathrm{X}$ mematahkan $\mathrm{Y}$ dengan mulut terbuka

Sesuatu terjadi pada $Y$

Y menjadi dua bagian

Pada saat itu terdengar bunyi tak

nglethuk 'menggigit benda agak keras'

$X$ melakukan sesuatu kepada $Y$

$X$ melakukan menggunakan gigi seri

$\mathrm{Y}$ adalah benda agak keras

$Y$ berukuran agak besar

$X$ mematahkan $\mathrm{Y}$ dengan mulut setengah tertutup

Sesuatu terjadi pada $Y$

Y menjadi beberapa bagian

Pada saat itu terdengar bunyi tuk

ngremus 'menggigit benda kecil agak keras'
$\mathrm{X}$ melakukan menggunakan geraham

$Y$ adalah benda agak keras

Y berukuran kecil (seperti pil)

$\mathrm{X}$ mematahkan $\mathrm{Y}$ dengan mulut tertutup

Sesuatu terjadi pada $Y$

Y menjadi beberapa bagian kecil

nglethus 'menggigit benda kecil yang agak keras tetapi kopong'

$X$ melakukan sesuatu pada $Y$

$\mathrm{X}$ melakukan dengan gigi seri

Y adalah benda kopong (seperti cabai)

$Y$ berukuran kecil

$\mathrm{X}$ mematahkan $\mathrm{Y}$ dengan mulut setengah tertutup

Sesuatu terjadi pada $\mathrm{Y}$

$Y$ menjadi dua bagian

Pada saat itu terdengar bunyi tus

nglethik 'menggigit benda keras berukuran kecil' $^{\prime}$

X melakukan sesuatu kepada $Y$

$X$ melakuka dengan gigi seri

$\mathrm{Y}$ adalah benda keras yang tipis

$Y$ berukuran agak kecil

$\mathrm{X}$ mematahkan $\mathrm{Y}$ dengan mulut setengah tertutup

Sesuatu terjadi pada $Y$

$Y$ menjadi dua bagian

Pada saat itu terdengar bunyi tik

\section{Simpulan}

Berdasarkan analisis disimpulkan bahwa ada 23 leksikon yang merealisasikan aktivitas gigi dalam bahasa Jawa. Setiap leksikon mewakili konsep makna berbedabeda bergantung pada pasien (objek) dan instrumen (cara melakukan aktivitas).

$X$ melakukan sesuatu pada $Y$ 
Verba aktivitas gigi terbentuk dari makna asali melakukan/terjadi dengan polisemi mengunyah, membawa, menggigit, melepaskan, dan mematahkan. Polisemi mengunyah menjelaskan aktivitas gigi dengan cara mengunyah objek yang digigit. Polisemi ini terdapat pada leksikon mamah, ngilut, ngenyoh, nggayem, ngemah, dan nginang. Keenam leksikon ini memiliki perbedaan dalam hal durasi dan proses setelah sesuatu itu halus.

Polisemi membawa menjelaskan aktivitas membawa sesuatu menggunakan gigi. Makna ini direalisasi oleh leksikon nggondol.

Polisemi menggigit menjelaskan aktivitas menggigit sesuatu. Makna ini direalisasi oleh leksikon nyakot/nyokot, nggeget, ngeret, ngerot, nyathèk, ngerah, dan nyekit. Leksikonleksikon ini berbeda dalam hal kuat-tidak dan lama-tidaknya gigitan.

Polisemi melepaskan menjelaskan aktivitas melepaskan sesuatu mengguna-kan gigi. Makna ini terdapat pada leksikon nyisil, ngrokot, ngrikit, dan mbrakot. Leksikon itu memiliki perbedaan dalam hal apa yang dilepaskan, jumlah yang dilepaskan, dan cara melepaskan.

Polisemi mematahkan menjelaskan aktivitas gigi yang membuat sebuah benda terbagi menjadi beberapa bagian. Makna ini direalisasi oleh leksikon nglethak, nglethuk, nglethus, ngremus, dan nglethik. Perbedaan leksikon-leksikon itu ada pada cara mematahkan benda menggunakan gigi tertentu, ukuran dan kekerasan benda yang dipatahkan, serta bunyi yang ditimbulkan ketika menggigit.

Penganalisisan sebuah leksikon menggunakan Metabahasa Semantik Alami ini mampu menjelaskan makna leksikon secara tuntas. Hal ini merupakan cara yang ampuh bagi seorang leksikograf dalam melakukan pendefinisian sebuah leksikon, utamanya leksikon-leksikon yang mirip.

\section{Daftar Pustaka}

Dewi, S. S. 2019. "Struktur Semantis Verba Kiru 'Potong' Kajian Metabahasa Semantik Alami". Izumi Jurnal Bahasa, Sastra, dan Budaya Jepang, 8 (2), 101--124. DOI: https:// doi.org/10.14710/izumi.8.2. 101-124

Givon, T. 1984. Syntax: A Functional Typological Introduction. Vol. I. Amsterdam: John Benjamins.

Goddard, C. 1996. "Building a Universal Semantic Metalanguage: The Semantic Theory of Anna Wierzbicka". In Cross Linguistic Syntax From A Semantic Point of View (NSM Approach) (pp. 24--37). Australian National University.

Goddard, C. 2012. "Semantic Primes, Semantic Molecules, Semantic Templates: Key Concepts in The NSM Approach to Lexical Typology". Linguistics, 50(3), 711--743. DOI: https:// doi.org/10.1515/ling-20120022

Khrisnantara, I Gde Yudhi Argangga, I Nengah Sudipa, I Ketut Darma Laksana. 2020. "Struktur Semantik Verba "Membawa" dalam Bahasa Osing Banyuwangi". Jurnal Pendidikan Bahasa dan Sastra Indonesia, 10(1), 96-102.

Kurniawan, M. A. 2014. "Leksikon Emotif Makna "Ketidaksukaan" dalam Bahasa Sasak: Kajian Metabahasa Semantik Alami". Verbalinguia Jurnal Ilmiah Kebahasaan, 1 (1), 42--51. 
Loe, E. E. Y. 2017. "Verba "Melukai" dalam Bahasa Rote Dialek Dengka: Kajian Meta Semantik Alami (MSA)". SASDAYA, Gadjah Mada Journal of Humanities, Vol.1 No. 2 (1), 219--234. https:// doi.org/10.22146/sasdayajo urnal.27783.

Maturbongs, A. 2016. "Peran Semantis Verba Bahasa Abun". Kandai, 12 (1), 17--37.

https:/ / doi.org/10.26499/jk.v12i1.69

Mayasari. 2020. "Verba Emosi Sedih dalam Bahasa Jawa: Kajian Semantis". Jurnal Education and Development, 8 (1), 374--376.

Miles, Matthew B., A.M. Huberman, dan J. S. 2014. Qualitative Data Analysis (A Methods Sourcebook). Arizona State University: Sage Publications.

Mulyadi. 2013. Verba "Mirip Takut" dalam Bahasa Melayu Asahan. Internatonal Seminar "Language Maintenance and Shift III," July 2--3, 331--335.

Nardiati, S. 2017. "Komponen Makna Leksem Berkonsep 'Empon-Empon' dalam Bahasa Jawa Widyaparwa, 45 (2), $165-180$. https:/ / doi.org/10.26499/wdprw.v4 $5 \mathrm{i} 2.233$

Ndruru, K. 2020. "Makna Verba "Membersihkan" dalam Bahasa Nias: Pendekatan Metabahasa Semantik Alami". Jurnal Education and Development Institut Pendidikan Tapanulis Selatan, 8 (3), 918--922.
Parwati, S. A. P. E. 2018. "Verba "Memasak" dalam Bahasa Bali: Kajian Metabahasa Semantik Alami (MSA)". Aksara, 30 (1), 121--132. https:/ / doi.org/10.29255/aksara.v30 i1.73.121-132

Rahayu, U. P., Mandala, H., Setiawan, I., Indonesia, P. B., \& Mataram, U. M. 2020. "Variasi Verba Memukul Bahasa Sasak di Kecamatan Kediri: Kajian Metabahasa Semantik Alami". Jurnal Ilmiah Telaah, 5 (2), 41--49. https://doi.org/10.31764/telaah.v5i 2.2622

Subiyanto, A. 2011. "Struktur Semantik Verba Proses Tipe Kejadian Bahasa Jawa: Kajian Metabahasa Semantik Alami". Kajian Linguistik dan Sastra, 23 (2), 165-176.

http://journals.ums.ac.id/index.php /KLS/article/view/4311/2740

Suktiningsih, W. 2017. "Struktur Semantis Verba "Membawa" Bahasa Sunda: Kajian Metabahasa Semantik Alami". Humanitatis: Journal on Language and Literature, 6 (July), 1--14.

Syahputra, F. P., \& Sinar, T. S. 2018. "Struktur Semantis Verba Sentuh Bahasa Indonesia". Haluan Sastra Budaya.

https:// doi.org/10.20961/hsb.v2i1.1 7484

Tualaka, D. 2016. "Struktur Semantik Verba Persepsi Bahasa Melayu Kupang: Perspektif Metabahasa Semantik Alami (MSA)". Jurnal Triton Pendidikan, 1 (1), 57--60. https:// doi.org/10.30862/jtp.v1i1.79 8 
Widani, N. N. 2017. "Makna "Mengambil" Bahasa Bali: Pendekatan Metabahasa Semantik Alami (MSA)". RETORIKA: Jurnal Ilmu Bahasa. https:// doi.org/10.22225/jr.2.1.53.12 7-141
Wierzbicka, A. 1996. Semantics: Primes and Universals. Oxford: Oxford University Press.

Yulianti, S. 2016. "Kosakata Warna Bahasa Sunda (Pendekatan Metabahasa Semantik Alami)". Ranah: Jurnal Kajian Bahasa, 5 (1), 74--86.

https://doi.org/10.26499/rnh.v5i1.39 